\title{
Tolerance as Cultured Generation Forming: Research on Yogyakarta Novel and A Million Prayers for Gus Gur by Damien Dematra
}

\author{
W Hermawan ${ }^{1}$, Suyitno ${ }^{2}$, HJ Waluyo ${ }^{3}$, and NE Wardhani ${ }^{4}$ \\ ${ }^{1}$ Doctoral Student of Sebelas Maret University, Surakarta, Indonesia \\ ${ }^{1,2}$ Faculty of Teacher Training and Education UNIM, Mojokerto, Indonesia \\ ${ }^{3}$ Faculty of Teacher Training and Education Sebelas Maret University, Surakarta, Indonesia \\ E-mail: wawanhermawan@student.uns.ac.id
}

\begin{abstract}
This study discusses tolerance and multiculturalism in the Yogyakarta novel and A Million Prayers for Gus Dur by Damien Dematra. The research objective is to explore diversity through tolerance. This study uses the perspective of literary sociology, tolerance, and multiculturalism. This research is a qualitative research. The results of the study indicate that, the author seeks to make aware of the existence of diversity manifested through tolerance. Both the character's portrayal and the storytelling of the characters directly or indirectly. There is a mission that the writer wants to convey from the novel, which is understanding and practicing multiculturalism. Yogyakarta novel and $A$ Million Prayers for Gus Dur by Damien Dematra are a symbol of diversity. Both (Yogyakarta and A Million Prayers for Gus Dur) illustrate the diversity of cultures, ethnicities, races, tribes, and religions, all of which are a pillar of diversity. Tolerance is reflected in the appreciation of the reality of cultural plurality in society and recognition of human dignity and human rights. Through diversity that is realized through tolerance, it is hoped that it can form a cultured generation.
\end{abstract}

Keyword: Tolerance; Multicultural; Novel.

\section{INTRODUCTION}

Tolerance is a characteristic of attitudes about diversity. This is reflected in the behavior of every society. Tolerance is manifested by respecting a difference in religion, ethnicity, and culture. The diversity of religions, ethnicities and cultures is seen as a multicultural society. Society will be called a multicultural society if in a community live two or more cultural and they are mutually respectful, respectful and tolerant [1]. Our country adheres to multiculturalism reflected in a mutually agreed symbol, namely Bhinneka Tunggal Ika. Bhinneka Tunggal Ika is 
an acknowledgment of ethnic heterogeneity, culture, religion, race and gender, but demands unity in the political commitment to build the Unitary Republic of Indonesia (NKRI).

Multicultural is expected to reconstruct a national culture that can bind all ethnic, cultural, and religous diversity. This is because in reality the community is still low in awareness of tolerance towards the diversity of ethnicity, culture, religion, race, and gender. Awarness (and pride) of shared identity as a nation, and shared historical awarness and the same and affinity, especially amog the younger generations now and in the future will decline [2]. If we are negligent in managing it (multicultural potential) it will produce conflicts containing SARA which will make this country face the threat of national disintegration which allows this country to split into hundreds of new countries [3].

This research seeks to discuss tolerance found in Yogyakarta [4] novel and A Million Prayers for Gus Dur [5] by Damien Dematra. Interest and reason for choosing Damien Dematra's work as the object of research studies because Damien Dematra is a multitalented person, both a novelist, director, producer, photographer and painter. In addition, Damien Dematra was active as the National Coordinator of the Pluralism Care Movement (GPP) and chair of the National Writing Movement (GNM), so the work produced reflected the author's social, ideological and cultural background.

The novel by Damien Dematra which is used as a study in literature is not yet using the perspective of literature sociology and the focus of representation on multicultural tolerance. This is seen from previous studies that examined novel by Damien Dematra who did not use the perspective of literary sociology in the study, including Febriani (2013) who used a structural perspective in researching Yogyakarta novel [6] and Adji (2011) using representation (Barker) and ideology ( Storey and Barthes) in the Yogyakarta novel by Damien Dematra [7]. So based on previous research, research on tolerance in Damien Dematra novel has never been done before, so this has become a novelty of research.

The focus of the study in this study is tolerance, multicultural, so that the perspective used is the sociology of literature. The sociology approach of work is one approach in analyzing a literary work by looking at a text from the socio-cultural community contained in the novel. Sociology of literature as an approach that considers social aspects in literature [8]. Literary sociology is an approach to literature that considers social aspects [9]. Perspective of literary sociology, literary works can be seen as a product of society, as a means of describing (representation) reality in society. Literature can also be a document of social, cultural and political realities that occur in society at certain times [10]. Sociology of literary works defeats the contents of literary works, goals, and other things that are implicit in the literary works themselves and those related to social problems [11].

\section{METHOD}

This type of research is qualitative research. Qualitative research is research that intends to understand the phenomena experienced by research subjects [12]. This study uses a sociological approach to literature. These data are data on multicultural values in novel Yogyakarta and A Million Prayers for Gus Dur by Damien Dematra. This research data is written data in the form of documents. This document data comes from objective data. The objective data in this study came from the novels Yogyakarta and A Million Prayers for Gus Dur by Damien Dematra which contained multicultural values both in terms of portrayal of characters and dialogue between leaders. The data analysis technique in this study uses content 
analysis techniques. Content analysis as a research technique for making replicable and valid inference from texts (or other meaningful matter) to the contexts of their use [13]. Test the validity of the data in qualitative research includes several tests. One uses the triangulation technique. Trianggulasi is defined as checking data from various sources in various ways and at various times. Trianggulasi technique consists of four types, namely triangulation of sources, methods, researchers, and theories [14]. The researcher used the theory triangulation test in this study. Triangulation theory is to use several theories so that the findings obtained are valid. The theory that serves as a reference for validating the findings in this study is the theory sociology of literature Wellek and Warren.

\section{RESULT AND DISCUSSION}

The results of the study show that there is tolerance in Yogyakarta novel and A Million Prayers for Gus Dur by Damien Dematra. Tolerance is reflected in the appreciation of the reality of cultural plurality in society and recognition of human rights and human rights. Diversity manifested in tolerance is expected to be able to form a cultured generation. The following are explained in both forms of tolerance.

\subsection{Appreciation of the existence of cultural plurality in society}

The first form of tolerance is an appreciation of the plurality of cultures in society. An appreciation of the plurality of cultures in society can be found in Yogyakarta novel and $A$ Million Prayers for Gus Dur by Damien Dematra. This can be seen in the table below.

Table 1. Appreciation of the existence of cultural plurality in society

\begin{tabular}{cl}
\hline Novel Title & \multicolumn{1}{c}{ Tolerance Data } \\
\hline Yogyakarta & "I live with four Muslim men and one Confucian, and \\
they are my best friends, Papa. Especially my boarding & house". (Dematra/Yogyakarta, 2010: 248). \\
\hline "Gerson looked at Olivia and saw the cross necklace on \\
his T-shirt, remembering Ananda's words that the girl \\
was a Catholic. He brushed aside the shadow of religious \\
differences and smiled at women". \\
(Dematra/Yogyakarta, 2010: 108). \\
"Muslims, Catholics, Protestants, Buddhists, Hindus \\
and Confucians chanted their prayers. The chanting of \\
the Javanese sentence was given". (Dematra/ A Million \\
Prayers for Gus Dur, 2010: 232). \\
"I know, you always tell me to be friends with as many \\
people as possible. " \\
Wahid Hasyim nodded. "Yes. Continue?" \\
"Even the difference in religion is not it, sir?" \\
"Yes. Even with different religions, "Wahid Hasyim said, \\
his feet walked lightly on the tile floor of his house". \\
(Dematral A Million Prayers for Gus Dur, 2010: 76-77).
\end{tabular}


"I live with four Muslim men and one Confucian, and they are my best friends, Papa. Especially my boarding house". [4]

The data above shows an appreciation for the existence of cultural plurality in society. The appreciation of the cultural plurality in society is reflected in the diversity of cultural, religious, and ethnic backgrounds of the characters in a novel told to a rental house in Yogyakarta. This shows that there is an acceptance, recognition, appreciation, and equality about a difference.

"Gerson looked at Olivia and saw the cross necklace on his T-shirt, remembering Ananda's words that the girl was a Catholic. He brushed aside the shadow of religious differences and smiled at women". [4]

Based on the data above it can be stated that there is a plurality of cultures in society. This can be seen from the character Gerson who can accept, confess, and appreciate his new friend named Olivia who has a different religion. the author tries to convey the message of tolerance through this novel. Appreciation of the plurality of cultures in society is not only found in Yogyakarta novel but also in the novel Sejuta Doa for Gus Dur. Can be seen in the quote below.

"Muslims, Catholics, Protestants, Buddhists, Hindus and Confucians chanted their prayers. The chanting of the Javanese sentence was given". [4]

Appreciation of the plurality of cultures in society is also found in Damien Dematra's Sejuta Doa for Gus Dur novel. An appreciation for the diversity of cultures, religions and ethnicities is seen from the diversity of Muslims, Catholics, Protestants, Hindus, Buddhists and Confucians who held a prayer together for Gus Dur who had died. The prayers offered also use Javanese culture.

"I know, you always tell me to be friends with as many people as possible. "

Wahid Hasyim nodded. "Yes. Continue?"

"Even the difference in religion is not it, sir?"

"Yes. Even with different religions, "Wahid Hasyim said, his feet walked lightly on the tile floor of his house". [4]

The data quoted above shows an appreciation of cultural plurality in society. This form of appreciation of the plurality of cultures is seen from the dialogue between the leaders of the father and son (between Wahid Hasyim and Abdurahman Wahid). Wahid Hasyim gave a message to his son, Abduraman Wahid, to be able to be friends with anyone, regardless of cultural, religious differences. The data above shows that the appreciation of cultural plurality is not only an individual's understanding and experience of diversity, but also provides understanding and experience to other people, especially family members, a manifestation of appreciation for cultural plurality in society.

\subsection{Recognition of human dignity and human rights}

Diversity manifested through tolerance does not only exist in a plurality of cultures. Rather, recognition of human dignity and human rights is a form of tolerance. The author tries to want an equality in difference. This can be shown in the table below. 
Table 2. Recognition of human dignity and human rights

\begin{tabular}{cl}
\hline Novel Title & Tolerance Data \\
\hline Yogyakarta & "I have a dream that all four of my children will one day \\
live in a country where they will not be judged based on & their skin color but from their character". \\
(Dematra/Yogyakarta, 2010: 86). & "If I myself will not do it, but if anyone does not mind and \\
feels able to live like that, yes ... it's up to each person" \\
(Dematra/Yogyakarta, 2010: 105). \\
\hline "Gus Dur celebrated a new year with Papuan leaders \\
A Million Prayers for \\
Gus Dur \\
for all groups present, how to humanize humans, and \\
how to uphold the rights and dignity of humans to be \\
returned to portions and heights ". (Dematra/ A Million \\
Prayers for Gus Dur, 2010: 155). \\
\hline "I will forever owe you. After all this time, I feel treated \\
as a human being again". (Dematra/ A Million Prayers \\
for Gus Dur, 2010: 46).
\end{tabular}

"I have a dream that all four of my children will one day live in a country where they will not be judged based on their skin color but from their character". (Dematra/Yogyakarta, 2010: 86).

The quote shows recognition of human dignity and human rights. It is seen from the desire to live a safe, peaceful and peaceful life. The absence of violence, all the differences that exist do not reduce the equality of human dignity and human rights. Besides the data above, it can also be seen in the quote below.

"If I myself will not do it, but if anyone does not mind and feels able to live like that, yes ... it's up to each person" [4]

The data above shows the recognition of human dignity and human rights. The data above shows that through diversity manifested by tolerance can create recognition of human dignity and human rights. Appreciation of the plurality of cultures in society is not only found in Yogyakarta novel but also in the novel A Million Prayers for Gus Dur. Can be seen in the quote below.

"Gus Dur celebrated a new year with Papuan leaders and people. How he behaves has provided a role model for all groups present, how to humanize humans, and how to uphold the rights and dignity of humans to be returned to portions and heights". [4]

Recognition of human dignity and human rights is also present in Damien Dematra A Million Prayers for Gus Dur novel. In the quote illustrates how humans can appreciate human dignity and human rights in proportion. How Gus Dur figures provide a role model for all people or figures in the community.

"I will forever owe you. After all this time, I feel treated as a human being again". 
The citation form of the data above shows the recognition of the existence of human dignity and human rights. This can be seen from the acknowledgment of one of the characters in the novel who revealed that Gus Dur treatment of him upheld human dignity and human rights. The author seeks to convey the message that the recognition of human rights and human rights can be implemented daily, so that it is expected to form a cultured generation.

Based on the findings, the researcher revealed that there was diversity manifested through tolerance in the Yogyakarta novel and A Million Prayers for Gus Dur by Damien Dematra. Tolerance is interpreted as an attitude or nature of human freedom to express his belief, run his religion freely, give someone to think differently, respect each other, tolerate, help each other and cooperate with fellow believers religious in building a safe and prosperous society [15].

Diversity that is promoted through tolerance with an appreciation of cultural plurality in society, and recognition of human dignity and human rights, reveals that there are four values or core values of multicultural education, namely appreciation for existence the reality of cultural plurality in society, recognition of human dignity and human rights, the development of world community responsibility, and the development of human responsibility towards planet earth [16].

The findings found in the novel by Damien Dematra show the existence of a diversity of religions, cultures that exist in multicultural societies. Multiculturalism is a concept about the recognition of a community of diversity, diversity and cultural differences, both ethnicity, race, ethnicity, religion, and so on [17]. Multicultural means of understanding diversity (plural) of culture (tradition) which is owned by a group of communities [18]. The form of multiculturalism that is manifested through tolerance is found in Yogyakarta novel and A Million Prayers for Gus Dur, which are reflected in dialogues between leaders and portrayals of characters both directly and indirectly.

\section{CONLUSION}

Based on the results and discussion stated that, there is tolerance in the Yogyakarta novel and A Million Prayers for Gus Dur by Damien Dematra. Tolerance shows the diversity that the author wants to convey through his novel. Both through portrayal of characters and the telling of figures directly or indirectly. Yogyakarta novel and A Million Prayers for Gus Dur by Damien Dematra are a symbol of diversity. Both (Yogyakarta and A Million Prayers for Gus Dur) illustrate the diversity of cultures, ethnicities, races, tribes, and religions, all of which are a pillar of diversity. Tolerance is reflected in the appreciation of the reality of cultural plurality in society and recognition of human dignity and human rights. Through diversity manifested through tolerance it is hoped that it can form a generation of culture.

\section{REFERENCES}

[1] T. A, "Multicultural Liteature: The Identity Construction in Indonesian Novels," Humaniora, vol. 26, no. 1, pp. 22-31, 2014.

[2] Syaifuddin AF, "Membumikan Multikulturalisme di Indonesia," ETNOVISI J. Antropol. Sos. Budaya, vol. 11, no. 1, pp. 3-11, 2006.

[3] Tan S, "Pendidikan Multikulturalisme: Solusi Ancaman Disintegrasi Bangsa," ETNOVISI J. Antropol. Sos. Budaya, vol. 11, no. 1, pp. 36-39, 2006. 
[4] Dematra D, Yogyakarta. Jakarta: Gramedia Pustaka Utama, 2010.

[5] Dematra D, Sejuta Doa untuk Gus Dur. Jakarta: Gramedia Pustaka Utama, 2010.

[6] Febriani, Memahami Novel Yogyakarta Karya Damien Dematra: Sebuah Kajian Struktural. Yogyakarta: Skripsi Program Studi Sastra Indonesia Univeristas Ahmad Dahlan, 2013.

[7] Adji SEP, "Representasi dan Ideologi Kota Yogyakarta dalam Novel Yogyakarta Karya Damien Dematra," J. Ilm. Kebahasaan dan Kesasteraan Widyaparwa, vol. 39, no. 2, 2011.

[8] Endraswara S, Metode Penelitian Sastra: Epistemologi, Model, Teori, dan Aplikasi. Yogyakarta: FBS Universitas Negeri Yogyakarta, 2011.

[9] Damono S D, Sosiologi Sastra Sebuah Pengantar Ringkas. Jakarta: Pusat Pembinaan dan Pengembangan Bahasa Departemen Pendidikan dan Kebudayaan, 1984.

[10] Wiyatmi, Sosiologi Sastra: Teori dan Kajian terhadap Sastra Indonesia. Yogyakarta: Kanwa Publiser, 2013.

[11] Wellek R and A. W, Teori Kesusastraan terjemahan Melani Budianta. Jakarta: PT Gramedia, 2016.

[12] Moeleong 1, Metodelogi Penelitian Kualitatif. Bandung: Remaja Rusdakarya, 2013.

[13] Krippendorff K, Content Analysis: An Introductions to its Methodology (Second Edition). California: Sage Publication, 2004.

[14] Sutopo HB, Metodologi Penelitian Kualitatif: Dasar Teori dan Terapannya dalam Penelitian. Surakarta: Universitas Sebelas Maret Press, 2006.

[15] Ali M, Pluralisme Agama di Persimpangan Menuju Tuhan. Salatiga: STAIN Salatiga Press, 2006.

[16] Tilaar HAR, Multikulturalisme Tantangan-Tantangan Global Masa Depan dalam Transformasi Pendidikan Nasional. Jakarta: Grasindo, 2004.

[17] Wahid A, Pergulatan Negara, Agama, dan Kebudayaan. Depok: Desantra, 2001.

[18] Mahfud C, Pendidikan Multikultural. Yogyakarta: Pustaka Pelajar, 2009. 